\title{
International Migration and the Nation State in Arab Countries
}

\author{
Philippe Fargues \\ Director, Migration Policy Centre \\ European University Institute, Italy
}

\begin{abstract}
International migration and the nation state have had, in all times and in all places, a difficult relationship. While the nation state is a community that recognises itself as one people sharing one territory and one narrative, international migrants are perceived as transgressors to the founding principle of the nation: emigrants, because they live outside the territory of which they still share the narrative; immigrants, because they are not yet part of the narrative attached to the territory in which they are newcomers. This article will, firstly, recall how Arab emigration in the age of nation-states has created an expatriate population that keeps links with its land of origin. It will show how states have shifted from disinterest and even distrust towards expatriates, to envisioning them as economic resources for national development and construction. The article will describe how development and security advantages, as compared with their African or Asian neighbours, have turned Arab states into receivers of new waves of international migrants and refugees, including a small minority of transit migrants stranded on their way to Europe, which some of them will reach clandestinely. While labour markets and, to a certain extent, societies are open to newcomers, Arab nation states demonstrate increasingly deny aliens full membership and, eventually, citizenship.
\end{abstract}

\section{Keywords}

Arab States; migrant worker; citizenship; diaspora; economics; development

\section{Introduction}

This contribution addresses international migration and its link with nationhood in Arab States today. ${ }^{1}$ International migration and the nation

1) This article is limited to the Arab states located on the Southern shore of the Mediterranean. From West to East: Morocco, Algeria, Tunisia, Libya, Egypt, Palestine, Jordan, Lebanon, and Syria. 
state have had, in all times and in all places, a difficult relationship. While the nation state is a community that recognises itself as one people sharing one territory and one narrative, international migrants are perceived as transgressors to the founding principle of the nation: emigrants, because they live outside the territory of which they still share the narrative; immigrants, because they are not yet part of the narrative attached to the territory in which they are newcomers. International migration is, therefore, a highly sensitive issue on nation states' political agendas.

The massive wave of popular unrest that is shaking the Arab region since the end of 2010 has much to do with nationhood and the way that citizens envisage the link between themselves as well as their relationship to the state. There is little doubt that the Arab Spring will have deep repercussions on the elements of nation making, including migration, the movement of peoples, and its management by states. But, at the time of writing, no one can tell what these changes will be. For this reason, this contribution must be considered as a stocktaking exercise before possibly radical changes, the magnitude and direction of which are, as yet, unknown.

All nations - Arab nations, just as any others - have both emigrants and immigrants who represent, at the same time, a hope and a worry with regard to fundamental societal issues such as welfare, progress, cohesion, security, and rights. As a general rule, migration is regarded differently by source and host states and opinions with the former viewing their emigrants as benefactors and the latter regarding immigrants as intruders. Migration is, indeed, the result of an imperfect world wracked by inequalities that set people on the move. At the sending end, there is the belief that emigrants will improve the lives of the families and communities left behind. Whilst, at the receiving end, there is the fear that immigrants will bring to their hosts some of the misery or unrest that pushed them to move in the first place. Nations regard expatriates in a very different way depending on whether they are theirs or whether they belong to others.

While international migration has become a matter for governance in most nations, its global governance has still to be established. Migration has become global, but there is no global regime to govern the international movement of persons. There is no migration law that could reasonably be described as "international", ${ }^{2}$ with the exception of international refugee

2) Ryszard Cholewinski, Richard Perruchoud, and Euan MacDonald, eds., International Migration Law: Developing Paradigms and Key Challenges (The Hague: TMC Acer Press, 2007). 
law, and no international institution to regulate the movement of persons that would be comparable to those for the movement of goods, services or capital.

To make the governance of migration still more difficult, there is a fundamental legal asymmetry in migration. While emigration is a right enshrined in international law (Article 13 of the Universal Declaration of Human Rights recognises the rights of individuals to leave any country, including their own), no law provides for the corresponding right to enter another country, for legislating on immigration is considered a matter of sovereignty. As a result, people are free to leave the country where they live, but they may have nowhere to go. ${ }^{3}$ This legal asymmetry translates in international politics when it comes to negotiating on migration issues. As a general rule, the sending state is in the position to make requests (e.g. pledging a more liberal visa policy) and the receiving state can set conditions before granting them (e.g. imposing a readmission agreement).

The article will, firstly, recall how Arab emigration in the age of nationstates has created an expatriate population —a "diaspora"4_that keeps links with its land of origin (section 1). It will show how states have shifted from disinterest and, sometimes, distrust towards their national expatriates to envisioning them as a resource to be mobilised for the (economic) construction of the nation, and building specific institutions in order to maintain transnational links and revive expatriates' Arab and Muslim identity (section 2). The article will then tackle the symmetrical dimension of migration and describe how development and security advantages, as compared with their African or Asian neighbours, have turned Arab states into receivers of new waves of international migrants and refugees, including a small minority of transit migrants stranded on their way to Europe, which some of them will reach clandestinely (section 3). While labour markets and, to a certain extent, societies are open to welcoming newcomers, Arab nation states demonstrate increasing closure to offering aliens full membership and, eventually, citizenship (section 4).

\footnotetext{
3) Seyla Benhabib, The Rights of Others:Aliens, Residents and Citizen (Cambridge: Cambridge University Press, 2004); Myron Weiner, "Ethics, National Sovereignty and the Control of Immigration," International Migration Review - Special Issue: Ethics, Migration, and Global Stewardship 30, no. 1 (Spring, 1996): 171-97.

4) "Diaspora", in this article, refers to permanent migrants and their descendants, irrespective of their forming a community, as opposed to a collection of individuals disconnected from each other, as well as their nourishing nostalgia for their remote homeland, as opposed to fully endorsing membership of the society where they live.
} 


\section{Rise and growth of Arab diasporas}

Long distance migration is consubstantial with the history of the Arabs. Migration, after all, has created the Arab world we know today, if one subscribes to the Banû Hilâl tale telling the story of a massive movement of tribes originating in Central Arabia and travelling through Southern Egypt to reach Tunisia and Morocco in the eleventh century. They were to bring the Arabic language to local Berber populations four hundred years after the Arab army brought them the Islamic faith. Movements of Arab merchants and clerks in all directions across the Muslim world have been common since the establishment of Islam. However, until the second half of the nineteenth century, most Arab migrants were bound for other regions within the vast area of what we would call today free circulation created by Islam $^{5}$ and later formalised by the Ottoman Empire. ${ }^{6}$

After some time, migrants would melt into the receiving population and become part of it. While the history of migration from the Maghreb to the Mashrek is still visible in frequent patronymics in Damascus or Cairo such as Al-Tunsi or Al-Jezairi, no one would speak of a Tunisian or an Algerian diaspora in Syria or in Egypt. With the long death agony of the Ottoman Empire and the concomitant establishment of colonial rule in the Arab world, Arab migrants started to reach other destinations in the Americas,

5) For Sami Adleeb Abu-Sahlieh, "According to the classical division dar al-islam/dar albarb, each Muslim is part of the Islamic Ummah and can sojourn wherever he wants in dar al-Islam benefiting from the same rights as other Muslims." "The Islamic Conception of Migration," International Migration Review 30, no. 1 (1996): 37-57. Commenting on Adleeb Abu-Sahlieh, Kemal Karpat describes the circulation and establishment of people across the Muslim world as a codified process: "The Arab migrations to North Africa, Egypt and Iraq, the Central Asian migrations to India, Iran and Anatolia, and the Turkish ones to the Balkans, occurred initially as a consequence of conquest but soon became matters of practical policies of settlement and peaceful accommodation with the conquered peoples thanks to the existence of an ethical-religious code of migration." "Muslim Migration: A Response to Aldeeb Abu-Sahlieh," International Migration Review 30, no. 1 (1996): 79-89.

6) The Ottoman nationality was defined by a law of 1869 . The Ottoman constitution of 1876 refers to the Ottoman nationality but does not define what rights it entails regarding the circulation and establishment of persons in the Empire. See "The Ottoman Constitution, Promulgated the 7th Zilbridje, 1293 (11/23 December, 1876)," reproduced in The American Journal of International Law 2, no. 4 (1908): 367-87. Karpat ("Muslim Migration", page 89) stresses that George Young's 1905-1906 treatise on "Corps du droit Ottoman" (1905-1906) dedicates 170 pages to Ottoman migration legislation. 
Africa, and Europe. What, today, one would call Arab diasporas were born. The determinants and patterns of long distance migration were not uniform across the Arab world and one can schematically make a distinction between the Mashrek (East of Libya) and the Maghreb (from Libya to Mauritania).

In the Mashrek, modern migration has often been triggered by conflict. ${ }^{7}$ The oldest wave of migrants departing from the region was sparked by communal strife breaking out in Mount Lebanon and Syria in the 186os, against the backdrop of the local economies being inexorably shaken by global trade, ${ }^{8}$ particularly by the silk cultivation that had once been the source of Mount Lebanon's wealth being supplanted by China's production. ${ }^{9}$ Pioneering overseas migration would soon be followed by recurrent outflows of new migrants, still continuing today, sometimes pushed by new conflicts, such as in Lebanon between 1975 and 1990, and, more often, pulled by the prosperity of a growing Lebanese, Syrian, and Palestinian diaspora in the Americas, Africa, Europe, and Australia. ${ }^{10}$

The unremitting conflict between Palestine and Israel has produced the largest migration movements among Arab populations, both directly and indirectly. Directly, the 1948 and 1967 wars caused two Palestinian exoduses and the ensuing political and economic predicament of the West Bank and Gaza Strip resulted in a constant flow of emigration from the Palestinian occupied territory; 11 indirectly, the conflict provided a strategic resource to Arab military regimes claiming their solidarity with the Palestinians and their belligerence against Israel, whose authoritarian rules became a strong driver of their own citizens' emigration.

The war of October 1973 is another key event explaining Arab migration. The battle unfolding on the Suez Canal and on the Golan heights was to produce, far away from the battlefield, a considerable impact on the

\footnotetext{
7) Philippe Fargues, "Les guerres, facteur décisif de migrations," Confluences Méditerranéennes 42 (2002): 23-35.

8) Charles Issawi, "The Historical background of Lebanese emigration, 1800-1914," in The Lebanese in the World - A century of emigration, eds. Albert Hourani and Nadim Shehadi (London: Centre for Lebanese Studies and I.B. Tauris, 1992), 13-21.

9) Dominique Chevallier, L'Economie du Mont Liban à l'époque de la révolution industrielle en Europe (Paris: Geuthner, 1971).

10) Boutros Labaki, "Lebanese Emigration during the War, 1975-1989," in The Lebanese in the World (see note 8), 605-26.

11) George Kossaifi, The Palestinian Refugees and the Right of Return (Washington, D.C.: Center for Policy Analysis on Palestine, 1996).
} 
economies of Arab oil countries and the societies of the whole Middle East. It was neither the uncertain outcome of the war, nor the first peace treaty ever signed between Israel and an Arab state (Camp David Treaty of 1979) that disrupted the economic and social order of the region. Rather, it was the invention of a new weapon of war - namely, oil. A few days after the war broke up, oil entered the battle: Saudi Arabia imposed an embargo on exports to the United States, thereby quadrupling its price. The wealth of oil producing countries soared and, consequently, so did their demand for imported labour.

Moreover, shortly after the war, President Sadat of Egypt pioneered his open-door policy, infitâh, which unlocked the borders of Egypt not only to foreign investment but also to the exit of millions of Egyptian workers. A nation with a several thousand years old sedentary tradition suddenly turned into the most dynamic labour exporter. Further, Egyptian migration was fostered by another conflict - the Iran-Iraq war of 1979-1988 - during which an estimated three quarters of a million Egyptians left the Nile Valley for the Euphrates and Tigris Valleys to replace Iraqi farmers enrolled in the army.

Then, the Gulf War of 1990-91 opened a new page in the history of Arab migration. It was the first large-scale military conflict to take place at the scene of a major crossroads of international labour migration and it caused an unprecedented ebb in the history of legal migration. Three million migrant workers, all with regular documents, were deported, ${ }^{12}$ a majority of them Arab citizens who had suddenly become 'unfaithful' because of their nationality. Three communities were particularly targeted: Egyptian peasants in Iraq, unskilled Yemeni construction workers in Saudi Arabia, and Palestinian white-collar workers in Kuwait. Moreover, the war was an occasion for the Gulf States to affirm national policies of indigenisation in the workforce. Policies failed to make their economies independent from labour imports, but they ended up gradually replacing Arab expatriates with Asians, ${ }^{13}$ who were viewed by employers as a more flexible workforce

\footnotetext{
12) Nicholas Van Haer, "Displaced people after the Gulf crisis," The Cambridge Survey of World Migration, ed. Robin Cohen (Cambridge University Press, Cambridge 1995), 424-30.

13) Andrzej Kapiszewski, "Arab Versus Asian Migrant Workers in the GCC Countries," United Nations Expert Group Meeting on International Migration and Development in the Arab Region (Beirut, 2006), http://www.un.org/esa/population/meetings/EGM_Ittmig_Arab/ Po2_Kapiszewski.pdf.
} 
and by states as a population less susceptible than Arabs - who share a common language and culture with the local society - to form a working class with its corresponding social and political claims. ${ }^{14}$

A war again, this time launched by the United States, Great Britain, and a few other Western states in 2003, was to trigger the largest wave of Arab refugees since 1948, when sectarian violence broke out soon after the American and European invasion of Iraq. Two million Iraqis refugees found shelter in nearby Arab countries between October 2005 and the end of $2007 \cdot{ }^{15}$ Jordan, Syria, and Lebanon, which were already the main host countries for Palestinian refugees, became the largest receivers of Iraqi refugees.

In contrast to the Arab East, where mass migration has been rooted in war and conflict, it was asymmetric economic integration operated by the colonial order that, above all, drove emigration from the Arab West. Labour migration from the Maghreb to France, then to other western European countries, started in the interwar years and gained momentum after WWII in response to the large-scale labour needs of post-war Europe. Far from slowing down, outflows of migrant workers from the Maghreb grew bigger when Tunisia (1956), Morocco (1956), and Algeria (1962) became independent nations, at the onset plagued by unemployment. Bilateral agreements were signed with several European states to manage guest workers programmes. At that time, migrants were all men moving back and forth between the Maghreb and Europe according to labour agendas.

The economic crisis of industrial economies, starting in 1973, in the wake of soaring oil prices, and the ensuing rise in unemployment, were to radically change how immigration worked in Western Europe. Governments closed the borders to the entry of foreign workers with the aim of curbing immigration, but they obtained just the opposite outcome. Migrants who were temporarily in Europe did not return to their homes for fear of not being allowed to re-enter Europe and, per European legislation on family reunification, their wives and children could join them. Visa restrictions had paradoxically transformed the two-way mobility of temporary male migrant workers into the one-way permanent immigration of mostly

14) Philippe Fargues, "Immigration without Inclusion: Non-Nationals in Nation-Building in the Gulf States," Asian and Pacific Migration Journal 20, no. 3-4 (2011): 273-92.

15) UNHCR, "Statistics on Displaced Iraqis around the World, Global Overview," September 2007, http://www.unhcr.org/470387fc2.pdf. 
inactive family dependents of migrants of former waves. ${ }^{16}$ Forces at play behind immigration were no longer the economic logics of labour markets, but the sociological drivers of families and networks. Legislations on naturalisation and jus soli then made populations originating in the Maghreb and their descendents a genuine part of national populations in Europe.

Not only did the containment of labour immigration result in booming family immigration, but it also produced a steady rise in irregular immigration. Indeed, while states closed the doors to migrant workers, labour markets did not. Actually, with the advent of middle classes in Europe, natives would no longer accept a number of low-skilled, low-paid jobs that only migrants would take. If they could not obtain the required permits, they would then enter, or stay, illegally. Because hiring under-protected underpaid workers met the interests of many employers, irregular migration became a large-scale response to visa restrictions. The phenomenon took momentum when Italy, then Spain and Greece took off economically in the 1990 and their well-established tradition of informal employment offered an avenue for irregular migrants. Informal employment was the true factor behind illegal immigration, not the other way around. ${ }^{17}$

While France and Western Europe had become more difficult destinations and southern Europe was attracting low-skilled, often irregular, migrants, rapidly rising levels of education in the Maghreb opened new doors for a new generation of would-be migrants. Either as students or as high-skilled workers, they started to consider destinations further out, such as French-speaking Canada and the United States. Others, often the less skilled, headed for Arab oil states in the Gulf and Libya. In the 200os, emigration from the Maghreb is, for a large part, cut off from its colonial and post-colonial roots.

On the eve of the uprisings that spread to the entire region in 2011 - and which have started to deeply reshape Arab societies, but, at the time of writing, with unforeseeable consequences for emigration - Arab Mediterranean countries were the source of a recorded 10.8 million emigrants; 12 million or more if unrecorded migrants are included. ${ }^{18}$ Migrants

16) Catherine Wihtol de Wenden, La question migratoire au XXIe siècle. Migrants, réfugiés et relations internationals (Paris: Presses de Sciences Po., 2010).

17) Emilio Reyneri, "Migrants in irregular employment in the Mediterranean countries of the European Union," International Migration Papers 41 (Geneva: ILO, 2001).

18) The total number in Table 1 underestimates real migrants stocks in 2010 for three reasons: estimates for the Gulf States refer to the year 2000 and emigration to the Gulf has been 
represent $5.3 \%$ (or, more likely, 6\%) of the population of their origin countries, which is roughly twice the $3.1 \%$ world average and demonstrates the very high propensity for migration among young Arabs.

Table 1 provides the distribution of out-migrants from Arab Mediterranean countries by region of destination and shows a striking divide between the Mashrek and the Maghreb. Migrants from the former go East and those from the latter go West: $79.9 \%$ of the Mashrek's émigrés reside in another Arab country, in the first instance in the Gulf States, if we except Palestinian refugees who continue to live in the neighbouring countries (Jordan, Syria, Lebanon, and Egypt) where their fathers or grandfathers found shelter in 1948 and 1967. On the other side of the Arab world, 92.2\% of Maghreb's émigrés live in the European Union and only $4.0 \%$ in another Arab country. To a certain extent, migration unites the Eastern part of the Arab world, but it divides the whole, or ratifies its division between East and West.

Table 1 also suggests that international migration is not as globalised as one would imagine. On the one hand, it has become a global phenomenon, not only because no country in the world is exempt from migrants, but also because migrants are no longer severed from their home countries, but are linked to it by modern means of communication and bound together, beyond borders, by transnational activities. Their networks have opened a new, non-state, dimension in international relations. On the other hand, despite distance being erased by low-cost flights and the Internet, migrants continue to go next door whenever it is possible. Proximity - geographic, historical or both - remains an overarching feature of migration in the Arab region. Egyptians are overwhelmingly found in nearby Saudi Arabia and in neighbouring Libya; Algerians and Tunisians continue to have France, whose language they often speak, as a preferred destination; as soon as its booming economy opened Spain to migration in the late 1990s, Moroccans were the first to move to Andalusia across the straits, where, a thousand years ago, their ancestors had once founded cities. The list could go on... Lebanon, with its unabated tradition of long distance emigration in all directions, is the only Arab nation with a truly global migration reach: only $11.8 \%$ of Lebanese first generation migrants live in nearby Arab countries (mostly the Gulf States), 30.1\% in the European Union, and 58.1\% dwell in other destinations in the Americas, Australia, and Africa, making the entire world a neighbour to Lebanon.

intense in the early 2000s; Egyptians and Tunisians in Libya - where they do not need an entry visa - are obviously underestimated; and a number of host countries are missing. 
Table 1 Migrants originating in Arab Mediterranean countries by region of residence; most recent data available in 2011

\begin{tabular}{lrrrrrr}
\hline & \multicolumn{5}{c}{ Region of residence } \\
\cline { 2 - 7 } $\begin{array}{l}\text { Country of } \\
\text { origin }\end{array}$ & $\begin{array}{l}\text { European } \\
\text { Union }\end{array}$ & Gulf States & Libya & $\begin{array}{l}\text { Other Arab } \\
\text { countries }\end{array}$ & $\begin{array}{l}\text { Other } \\
\text { countries }\end{array}$ & Total \\
\hline Egypt & 199,153 & $1,132,091$ & 164,348 & 121,082 & 226,661 & $1,843,335$ \\
Jordan & 25,745 & 168,668 & 2,053 & 48,990 & 78,195 & 323,651 \\
Lebanon & 153,196 & 52,543 & 966 & 6,635 & 296,065 & 509,405 \\
Palestine & 8,401 & 136,573 & 28,596 & $2,699,280$ & 34,530 & $2,907,380$ \\
Syria & 109,913 & 120,524 & 17,017 & 91,477 & 82,482 & 421,413 \\
Sub-Total & 496,408 & $1,610,399$ & 212,980 & $2,967,464$ & 717,933 & $6,005,184$ \\
Mashrek & & & & & & \\
Algeria & $1,475,662$ & 19,595 & 4,593 & 21,850 & 56,310 & $1,578,010$ \\
Libya & 43,646 & 2,035 & & 6,928 & 10,947 & 63,556 \\
Mauritania & 26,518 & 1,012 & & 3,174 & 2,648 & 33,352 \\
Morocco & $2,390,174$ & 46,544 & 19,839 & 26,279 & 92,522 & $2,575,358$ \\
Tunisia & 516,440 & 15,985 & 14,124 & 11,311 & 20,308 & 578,168 \\
Sub-Total & $4,452,440$ & 85,171 & 38,556 & 69,542 & 182,735 & $4,828,444$ \\
Maghreb & & & & & & \\
Total & $\mathbf{4 , 9 4 8 , 8 4 8}$ & $\mathbf{1 , 6 9 5 , 5 7 0}$ & $\mathbf{2 5 1 , 5 3 6}$ & $\mathbf{3 , 0 3 7 , 0 0 6}$ & $\mathbf{9 0 0 , 6 6 8}$ & $\mathbf{1 0 , 8 3 3 , 6 2 8}$ \\
\hline
\end{tabular}

Source: data from national population censuses of countries of residence (destination) compiled by A. di Bartolomeo for CARIM - EUI. Migrants are defined as "foreign-born" (preferred option) or "non-nationals" (second best) according to countries of residence. Palestinians are a special case, with refugees being counted as migrants even though in most cases their fathers, not themselves have made the move, and part of them (mostly those living in Jordan) have been granted citizenship of their country of residence.

NB: Table 1 does not provide numbers of people in the "diasporas", an ill-defined population impossible to enumerate.

Not only is Arab emigration twice as high as the world average, but its recent growth and its potential for future growth seem equally high. Before two major events that may have slowed down flows of Arab emigration the economic crisis in Europe and in the Gulf States starting in 2008, and the 2011 war in Libya provoking the return en masse of a million and a half non-nationals working there - emigration from the Mashrek and the Maghreb was showing no sign of abatement.

The number of Moroccan expatriates, for example, rose from 1.545 million in 1993 to 3.293 million in 2007, representing an average annual rate of growth of $5.4 \%$, more than four times higher than that of the total 
Table 2 Increase in Moroccan migrant stocks in South-Western Europe 1990-2010

\begin{tabular}{lccc}
\hline \multirow{2}{*}{ Country } & \multicolumn{2}{c}{ Absolute numbers } & \\
\cline { 2 - 3 } & Initial date & Most recent date & Annual rate of increase\% \\
\hline France 1993-2007 & 678,917 & $1,131,000$ & 3.6 \\
Spain 1998-2010 & 190,497 & 760,238 & 11.5 \\
Italy 1993-2009 & $66,5^{26}$ & 441,137 & 11.8 \\
\hline
\end{tabular}

Sources: France, Registres consulaires du Royaume du Maroc; Italy, Permessi di soggiorno, ISTAT; Spain, Padrón Municipal, INE

Table 3 Wish to emigrate among Tunisian youth 1996-2005

Percentage of people aged 15-30 who declare that they wish to $1996 \quad 20002005$ emigrate

\begin{tabular}{lllll}
\hline Sex & Male & 29 & 54 & 84 \\
\multirow{3}{*}{ Activity } & Female & 14 & 37 & 66 \\
& Employed & 25 & 48 & 77 \\
& Unemployed & 31 & 54 & 85 \\
\multirow{2}{*}{ Total } & Student & 26 & 48 & 75 \\
& & 22 & 45 & 76 \\
\hline
\end{tabular}

Source: Fourati, Habib 2008, Consultations de la jeunesse et désir d'émigrer chez les jeunes en Tunisie 1996 - 2005, CARIM

NB : National representative sample [size: 20,000 in 1996; 10,000 in 2000;10,000 in 2005]

population in Morocco ( $1.2 \%$ per year). Table 2 shows that the steady increase in Moroccan migrant stocks has continued through the years of economic crisis in France, Italy, and Spain, the main recipients of Moroccan migrants. Even in Spain, one of the countries hit hardest by the crisis, their number kept growing at a rapid pace: by $5.0 \%$ in $2007,9.5 \%$ in $2008,7.7 \%$ in 2009, and, still, $3.0 \%$ in 2010, at a moment when unemployment was reaching an unprecedented $23 \%$ among native Spaniards.

Surveys conducted in the period preceding the 2011 uprisings showed an overwhelming desire to emigrate among Arab youth. It was nowhere as high as in Tunisia (Table 3 ), where, in $2006,76 \%$ of the age group 15-30 years declared that they would like to emigrate, versus $22 \%$ in 1996 and $45 \%$ in 200o. While they would certainly not all take actual steps to leave their country, their wishing here reveals how deep the discontent of young adults deprived of economic and, perhaps as importantly, of political prospects, had sunk. 


\section{Courting national expatriates}

How do states view the emigration of their citizens - first, their leaving the nation, and, second, their maintaining a relationship with it once abroad? While these two questions have received various responses from a political, idealistic point of view - from seeing expatriates as traitors to the nation, to naming them its ambassadors - there seems to be an economic, pragmatic agreement that émigrés can serve the prosperity of their nation of origin.

From the outset, employment has been a nagging challenge for young Arab nations. In the first years of the nation-building process, sovietinspired socialism was in fashion and mobilising national workforce was seen as an avenue for development. States were held accountable for creating as many jobs as possible in the large farms, plants, and businesses under their ownership. As a corollary, they would not let their citizens leave the national territory and some of them would limit emigration to often inaccessible and, at best, sparingly granted, exit visas. When, in the late $1970 \mathrm{~s}$ and 1980s, states' failure to achieve full employment became patent and IMF recommendations to liberalise and de-nationalise firms - the so-called "structural adjustment" - spread across the developing world, unemployment soared and governments started to reassess their position on emigration. While they would not openly incite their citizens to seek fortune abroad, they viewed emigration as a safety valve and did nothing to discourage their citizens from leaving the country.

While Arab states never lamented the emigration of low-skilled workers, which they view as relieving the strain on employment, some qualify the emigration of high-skilled workers a brain drain and a loss of a scarce resource. Even though unemployment has now climbed all the grades of the skill ladder and hits young people with a university education more than any other group in Arab labour markets, some states and opinion leaders continue to view the emigration of their university-educated citizens as a pillage orchestrated by the receiving country. This vision is more widespread among intellectuals and opinion leaders than among governments, and more in the Maghreb than in the Mashrek. Indeed, in the Mashrek, it is commonly admitted, if not encouraged, that universities offer curricula specially targeting the needs of external labour markets, in particular those of the Gulf, so that educating citizens and providing them with technical skills then becomes part and parcel of a national export strategy.

Emigrants are absent. While they have always been present in the memories of their families and communities of origin, states did not pay much 
attention to them until the second half of the twentieth century, when the model of the nation-state started to impose itself on the whole world. Linking people transnationally, then, became not only the private affair it had been, but also a matter for state policies and politics. Arab states developed links with their expatriates ${ }^{19}$ - economic links in the first instance, then cultural, and now political.

The search for a better and wealthier life being the first driver of emigration, the economy was also the main reason why states started to have an interest in their émigrés. Transforming expatriates into actors in the development of their nation of origin, attracting their money, making use of their skills, and tapping their business networks became a stake for all Arab governments. State institutions and, sometimes, full ministries were created to foster the economic link between diasporas and the homeland (Table 4). Emigration is now regarded as a resource for national economies in the same way, if not at the same level, as trade - after all, families and states invest in growing and educating their children and, in the case of those children leave the country, remittances are a kind of return on families' and states' initial investment in children. In 2010, migrant workers' remittances represented 1.3\% of the GDP in Algeria, 2.6\% in Syria, 3.0\% in Egypt, $4.4 \%$ in Tunisia, $6.8 \%$ in Morocco, as high as $12.8 \%$ in Jordan, and the world record of $19.6 \%$ in Lebanon. ${ }^{20}$ Money received every year from national expatriates represents $3.3 \%$ of total exports of goods and services in Algeria, $7.4 \%$ in Syria, 9.1\% in Tunisia, $13.9 \%$ in Egypt, $28.7 \%$ in Jordan, and a critically high $93.4 \%$ in Lebanon, ${ }^{21}$ making the emigration of labour force the most profitable export for many Arab economies.

19) Laurie Brand, Citizens Abroad: Emigration and the State in Middle East and North Africa, (New York: Cambridge University Press, 2006); Philippe Fargues, "Arab Migration to Europe: Trends and Policies," International Migration Review 38, no. 4 (Winter 2004): 1348-71.

20) Extreme dependence on migrants' remittances has been one of the most stable features of the Lebanese economy over the whole XXth century. As early as 1917, an inspector of public works and agriculture could establish that remittances from the USA amounted to 90 millions piastres, representing $40 \%$ of the 220 million total national income. World Bank, Migration and Remittance Data, http://econ.worldbank.org/WBSITE/EXTERNAL/EXTDEC/ EXTDECPROSPECTS/o,,contentMDK:22759429 pagePK:64165401 piPK:64165026 theSitePK:476883,oo.html.

21) For figures for 2010 from the World Bank, see http://econ.worldbank.org/WBSITE/ EXTERNAL/EXTDEC/EXTDECPROSPECTS/o,,contentMDK:22759429 pagePK:64165401 piPK :64165026 theSitePK:476883,oo.html. 
For migrants to remit money to their country of origin, they need to have faith in its monetary system. Those Arab states with a strict state-controlled monetary system in the years of state-centred economy (roughly the 1960s and 1970s) undertook banking reforms in the 1980s and 1990s to make local currencies convertible and facilitate direct investments from abroad. This would allow migrant workers' remittances, which were previously depleted, if not deterred, by the many hurdles to circumvent, to now be freely channelled through visible, traceable avenues. Emigration became a driver of monetary liberalisation. By the same token, remittances allowed fragile economies to stabilise, as they have been found to be one of the most resilient sources of income in crisis times. ${ }^{22}$

Lebanon, with its legendary open economy, is a perfect illustration of how instrumental émigrés trusting a monetary system can be. Lebanon's fifteen-year civil war (1975-90) had devastating effects in both demographic terms, with one quarter of the population migrating out of the country, and economic terms, with fighting leaving infrastructures in ruins. Yet, through all of this, the banking system remained untouched: perhaps symbolically, Ryad Solh Street - the 'banks street' - was the only part of central Beirut that was never bombed. With Lebanese émigrés trusting nothing in Lebanon but its monetary system, money from abroad made up for the broken-down domestic economy and allowed the living standards of the Lebanese population not to drop as low as everyone would have feared possible.

Remittances, however, are individual savings primarily channelled by families. Migrants remit money to their country of origin as long as they have close dependent relatives still living there. With the passing of time and family reunification taking place in the host country, ties tend to weaken and flows of remittances dry up; this is why sustained inflows of remittances require continuous outflows of new migrants. For durably settled émigrés to continue to invest in their country of origin, they need to keep up a sense of belonging to that country. With migration becoming global and Arab migrants settling beyond the limits of the Arab world and culture, their sons and daughters tend to lose their Arabic, and their Arab identity grows steadily weaker. Encouraging migrants to maintain their Arab, and often Muslim, identity has become one dimension in states of origins' policies. To this end, they established cultural centres providing

22) Dillip Ratha and Ibrahim Sirkeci, "Remittances and the global financial crisis," Migration Letters 7, no. 2 (2010): 125-31. 
language courses and religious education to second-generation migrants in the countries where they live. Several states also offered their expatriate nationals opportunities to spend holidays in the country of their ancestors, from summer camps for young people to advantageous loans and tax exemption when acquiring real estate in tourist resorts, thereby combining two goals: economic and cultural.

Fully integrating expatriate communities in their country of origin would also imply that this country grants its nationals residing abroad full voting and eligibility rights, and their sons and daughters born abroad with foreign citizenship the nationality their parents. Few Arab countries have taken all these steps to date (Table 4). While all Arab states have a system of jus sanguinis by descent of father, which allows born-abroad children to claim the nationality of their Arab father, the same would not traditionally apply when only the mother has an Arab nationality. Gaining the right to transmit their nationality to their children is a conquest that only Tunisian (1963), Egyptian (2004), Algerian (2005), and Moroccan (2007) women have been able to accomplish in the Arab world. Recognition of dual citizenship was also gained in several countries. But, unrestricted political participation, including voting rights and, above all, eligibility in the country of origin was granted nowhere save in Morocco, which is the only state where such rights are now fully embedded in the constitution, a constitution drafted in 2011 in the wake of the Arab Spring. ${ }^{23}$

Various reasons explain why émigrés are more often excluded than included in the polities of their country of origin. In Tunisia, as well as in Algeria, before the revolution of 2011, the government distrusted the

23) Royaume du Maroc, Bulletin Officiel, 28 Chaaban 1432, 30 juillet 2011.; Dahir 1-11-91 du 27 Chaaban 1432, 29 juillet 2011, portant promulgation du texte de la Constitution, 1902-27. "ARTICLE 16. Le Royaume du Maroc œuvre à la protection des droits et des intérêts légitimes des citoyennes et des citoyens marocains résidant à l'étranger, dans le respect du droit international et des lois en vigueur dans les pays d'accueil. Il s'attache au maintien et au développement de leurs liens humains, notamment culturels, avec le Royaume et à la préservation de leur identité nationale. Il veille au renforcement de leur contribution au développement de leur patrie, le Maroc, et au resserrement des liens d'amitié et de coopération avec les gouvernements et les sociétés des pays où ils résident ou dont ils sont aussi citoyens.

ARTICLE 17. Les Marocains résidant à l'étranger jouissent des droits de pleine citoyenneté, y compris le droit d'être électeurs et éligibles. Ils peuvent se porter candidats aux élections au niveau des listes et des circonscriptions électorales locales, régionales et nationales. La loi fixe les critères spécifiques d'éligibilité et d'incompatibilité. Elle détermine de même les conditions et les modalités de l'exercice effectif du droit de vote et de candidature à partir des pays de résidence." 
Table 4 Selected institutions and legislation governing the link between national expatriates and their country of origin in Arab Mediterranean countries

\begin{tabular}{|c|c|c|}
\hline Country & Institutions* & Legislations \\
\hline \multicolumn{3}{|l|}{ Mashrek } \\
\hline Egypt & $\begin{array}{l}\text { Ministry of } \\
\text { Manpower and } \\
\text { Emigration }\end{array}$ & $\begin{array}{l}\text { Law } \mathrm{n}^{\circ} 111 \text { of } 1983 \text { on Emigration } \\
\text { and Egyptians' Welfare Abroad: the } \\
\text { state is committed to keeping up } \\
\text { links with national expatriates. } \\
\text { Law } \mathrm{n}^{\circ} 54 \text { of } 2004 \text { on nationality: Jus } \\
\text { sanguinis by descent of father or } \\
\text { mother; dual nationality allowed } \\
\text { for long-term emigrants. }\end{array}$ \\
\hline Jordan & None & $\begin{array}{l}\text { Law } n^{\circ} 6 \text { of } 1954 \text { amended in } 1987 \text { : } \\
\text { Jus sanguinis by descent of father. }\end{array}$ \\
\hline Lebanon & $\begin{array}{l}\text { Ministry of Foreign } \\
\text { Affairs and Lebanese } \\
\text { Expatriates abroad }\end{array}$ & $\begin{array}{l}\text { Nationality law of January } 11,1960 \text { : } \\
\text { Jus sanguinis by descent of father. } \\
\text { No political rights for Lebanese } \\
\text { abroad. Voting must be done in } \\
\text { Lebanon. }\end{array}$ \\
\hline Palestine & $\begin{array}{l}\text { Department of } \\
\text { Refugees Affairs. } \\
\text { Creation in } 2007 \text { of } \\
\text { a Department of } \\
\text { Palestinian } \\
\text { Expatriates }\end{array}$ & $\begin{array}{l}\text { Border and Refugee issues were not } \\
\text { transferred to the Palestinian } \\
\text { Authority (PA) jurisdiction in } 1995 \\
\text { and the Palestinian Basic Law does } \\
\text { not refer to them. Each Palestinian } \\
\text { has to have an identity number } \\
\text { (issued by Israel) and a travel } \\
\text { document (issued by the PA). } \\
\text { Entry and exit visas delivered by the } \\
\text { Israeli authorities. }\end{array}$ \\
\hline Syria & $\begin{array}{l}\text { Ministry of Foreign } \\
\text { Affairs and Emigrants }\end{array}$ & $\begin{array}{l}\text { The right to leave the country is not } \\
\text { guaranteed in the Constitution. } \\
\text { Legislative decree } n^{\circ} 276 \text { on the Syrian } \\
\text { Arab nationality:Jus sanguinis by } \\
\text { descent of father. }\end{array}$ \\
\hline \multicolumn{3}{|l|}{ Maghreb } \\
\hline Algeria & $\begin{array}{l}\text { Delegate Ministry in charge } \\
\text { of the } \\
\text { National Community } \\
\text { Established }\end{array}$ & $\begin{array}{l}\text { February } 27,2005 \text { modification of } \\
\text { Ordinance } \mathrm{n}^{\circ} 70-86 \text { of } 15 \text { December } \\
1970 \text { on nationality: Jus sanguinis } \\
\text { by descent of father or mother. }\end{array}$ \\
\hline
\end{tabular}


Table 4 (Cont.)

\begin{tabular}{|c|c|c|}
\hline Country & Institutions* & Legislations \\
\hline & $\begin{array}{l}\text { AbroadConsultative } \\
\text { Council for the National } \\
\text { Community Abroad }\end{array}$ & $\begin{array}{l}\text { Emigrés vote through consulates for } \\
\text { presidential, referendum, and } \\
\text { general elections; by proxy for } \\
\text { elections in popular assemblies in } \\
\text { communes and wilayas } \\
\text { (governorates). }\end{array}$ \\
\hline Libya & n.a. & $\begin{array}{l}\text { Freedom to leave the country guaran- } \\
\text { teed in the } 1988 \text { Great Green } \\
\text { Charter of Human Rights. }\end{array}$ \\
\hline Mauritania & $\begin{array}{l}\text { Ministry of Economic } \\
\text { Affairs and } \\
\text { Development; specific } \\
\text { governmental } \\
\text { committees dealing } \\
\text { with migration } \\
\text { management }\end{array}$ & $\begin{array}{l}\text { Law } \mathrm{n}^{\circ} 1961-112 \text { on Nationality } \\
\text { modified in } 1962 \text { and } 1976 \text { : Jus } \\
\text { sanguinis by descent of father or } \\
\text { mother, though persisting sex } \\
\text { discrimination. } \\
\text { Electoral representation of expatriates } \\
\text { in the Senate and the Economic and } \\
\text { Social Council. }\end{array}$ \\
\hline Morocco & $\begin{array}{l}\text { Ministry in Charge of } \\
\text { Moroccans Residing } \\
\text { Abroad (MRE); } \\
\text { Council of the Moroccan } \\
\text { Community Residing } \\
\text { Abroad (CCME); } \\
\text { Hassan II Foundation for } \\
\text { Moroccans Residing } \\
\text { Abroad }\end{array}$ & $\begin{array}{l}\text { Nationality code of 2007:Jus sanguinis } \\
\text { by descent of father and mother, } \\
\text { though persisting sex } \\
\text { discrimination. } \\
2011 \text { Constitution: Moroccans residing } \\
\text { abroad enjoy full voting and } \\
\text { eligibility rights (Article 17); State } \\
\text { authorities work for expanding the } \\
\text { participation of Moroccans residing } \\
\text { abroad in all consultative and } \\
\text { governance institutions (Article 18) } \\
\text { created by the constitution and the } \\
\text { law. }\end{array}$ \\
\hline Tunisia & $\begin{array}{l}\text { Office of Tunisians Abroad } \\
\text { (OTE) } \\
\text { High Council for Tunisians } \\
\text { Abroad (HCTE) }\end{array}$ & $\begin{array}{l}\text { Decree-Law } \mathrm{n}^{\circ} 63-6 \text { of February } 28 \text {, } \\
1963 \text { :Jus sanguinis by descent of } \\
\text { father or mother. } \\
\text { Expatriates have voting and eligibility } \\
\text { rights. }\end{array}$ \\
\hline
\end{tabular}

* List of institutions updated at the end of 2010.

Source: CARIM Migration Profiles, by country, http://www.carim.org/index.php ?callContent $=502$. 
diaspora that was regarded as sheltering political opponents banned by the regime. And, indeed, several high-level politicians serving in Tunisia's first post-revolution government, including the President of the Republic, were political exiles in Europe. In Lebanon, émigrés' voting has long been a bone of contention between political parties and it became part of a heated debate in the 2009 parliamentary elections. ${ }^{24}$ Who amongst those actually or potentially claiming a Lebanese identity should be allowed to participate in the political life of a country from where emigration has been a massive fact over the last 150 years? Would their voting not endanger the fragile political balance between religious communities, given that successive waves of Lebanese emigration had different communal composition and given that some communities emigrated more often than others? Faced with these dilemmas, the Lebanese government has opted for a solution that does not deny voting rights to national expatriates, but limits their actual use of this right by stating that voting can only be made on the national territory of Lebanon. As a result, only a few thousand expatriate Lebanese could afford the travel to Lebanon to participate in the 2009 elections.

\section{Arab states at the crossroads of regional labour and refugee movements}

Mobility is in both directions and nations are not only faced with their own citizens departing and settling abroad but also with others' citizens arriving on their territory. Arab Mediterranean states were host to an estimated 4.5 million international migrants in 2005. Two thirds of them were economic migrants and one third were refugees (Table 5 ).

Economic migrants mainly come from neighbouring countries (Syrians in Lebanon, Sudanese nationals in Egypt, Egyptians and Tunisians in Libya...), but also from more distant origins (Chinese nationals in Algeria, Bangladeshis in Jordan...); they fill low-skilled jobs that no longer attract natives in the building sector, in agriculture, and in domestic services. They also include persons waiting for a visa or, if they cannot obtain one, for a

24) Thibaut Jaulin, "L'Etat libanais et sa diaspora : enjeux confessionnels, usages politiques, dynamiques économiques" (doctoral thesis in political science, Ecole doctorale de Sciences juridiques et politiques, Université Paul Cézanne, 2009), 461. 
Table 5 Immigrants in Arab Mediterranean countries (ca. 2005)

\begin{tabular}{|c|c|c|c|c|c|c|}
\hline \multirow[t]{2}{*}{ Country } & \multirow{2}{*}{$\begin{array}{l}\text { Regular } \\
\text { immi- } \\
\text { grants }\end{array}$} & \multicolumn{4}{|c|}{ Irregular immigrants } & \multirow{2}{*}{$\begin{array}{l}\text { Total } \\
\text { immigrants }\end{array}$} \\
\hline & & $\begin{array}{l}\text { Migrant } \\
\text { workers }\end{array}$ & $\begin{array}{l}\text { De facto } \\
\text { refugees }\end{array}$ & Transit & $\begin{array}{l}\text { Total } \\
\text { irregular }\end{array}$ & \\
\hline Egypt & 115,589 & $\begin{array}{l}\text { Tens of } \\
\text { thousands }\end{array}$ & 104,390 & n.a. & $\geq 100,000$ & $\geq 215,000$ \\
\hline Jordan & 392,273 & $\begin{array}{l}\text { 100,ooo or } \\
\text { more }\end{array}$ & $5^{19,477}$ & n.a. & $\geq 600,000$ & $\geq 1,000,000$ \\
\hline Lebanon & 302,315 & $\begin{array}{l}400- \\
500,000\end{array}$ & 22,743 & n.a. & $\geq 400,000$ & $\geq 700,000$ \\
\hline Palestine & n.a. & n.a. & n.a. & n.a. & n.a. & n.a. \\
\hline Syria & 55,000 & Thousands & 707,422 & n.a. & $\geq 700,000$ & $\geq 750,000$ \\
\hline $\begin{array}{l}\text { Sub-Total } \\
\text { Mashreq }\end{array}$ & 865,177 & $\begin{array}{c}500,000 \text { or } \\
\text { more }\end{array}$ & $1,354,032$ & n.a. & $\geq 1,800,000$ & $\geq 2,665,000$ \\
\hline Algeria & 80,238 & $\begin{array}{l}\text { Tens of } \\
\text { thousands }\end{array}$ & 95,121 & $\begin{array}{l}\text { Tens of } \\
\text { thousands }\end{array}$ & $\geq 10,000$ & $\geq 185,000$ \\
\hline Libya & 449,065 & $\begin{array}{l}1.0-1.2 \\
\text { million }\end{array}$ & 4,754 & $\begin{array}{l}\text { Tens of } \\
\text { thousands }\end{array}$ & $\geq 1,000,000$ & $\geq 1,45^{0}, 000$ \\
\hline Mauritania & 48,000 & $\begin{array}{l}\text { Few } \\
\text { thousands }\end{array}$ & 861 & $\begin{array}{l}\text { Tens of } \\
\text { thousands }\end{array}$ & $\geq 10,000$ & $\geq 60,000$ \\
\hline Morocco & 62,348 & $\begin{array}{l}\text { Tens of } \\
\text { thousands }\end{array}$ & 1,878 & $\begin{array}{l}\text { Tens of } \\
\text { thousands }\end{array}$ & $\geq 10,000$ & $\geq 70,000$ \\
\hline Tunisia & 35,192 & Thousands & 161 & n.a. & $\geq 10,000$ & $\geq 45,000$ \\
\hline $\begin{array}{l}\text { Sub-Total } \\
\text { Maghreb }\end{array}$ & 639,651 & & 102,614 & & $\geq 1,040,000$ & $\geq 1,810,000$ \\
\hline Total & $1,540,020$ & 2-3 million & $1,456,807$ & $\begin{array}{l}5^{0,000} \\
-150,000\end{array}$ & $\geq 2,840,000$ & $4,475,000$ \\
\hline
\end{tabular}

Source: Fargues, 2009.

clandestine passage to Europe - the so-called 'transit' migrants whose number would be in the tens of thousands, but not the big crowd that European policy efforts to counter irregular migration sometimes suggest. Because it is not the local labour market that primarily attracts transit migrants but the opportunity a country offers to reach a further, more attractive, destination, they are in a transient situation that cannot last very long: either they successfully leave the country (or return to their point of departure), or 
they stay and join the much larger group of economic migrants employed in low-skilled, low-paid activities.

While immigration had existed in all times (flows from other parts of the Ottoman Empire to Lebanon and Syria, colonial migration from Europe to the Maghreb, Jewish migration to Palestine then Israel, etc.), it is only in the last decade of the twentieth century that irregular migrants, i.e. persons whose entry, stay or employment is unauthorized, started to gain momentum in the Arab Mediterranean countries. Mashrek and Maghreb states have let irregularity become an ordinary situation, either because they lack the tools to incorporate immigrants or because the political will to do so is simply not there. ${ }^{25}$ Before the uprisings of 2011 , which led most migrants in Libya and probably many Iraqi refugees in Syria to return to their home countries, foreign nationals with one form or another of irregular situation had become a majority among immigrants in the region.

On the eve of the Arab Spring that resulted in many of them being displaced, irregular migrant workers were estimated at between 2 and 3 million people, compared with 1.5 million legal migrant workers (Table 4). They are mainly found in the large informal sector of Arab economies where all workers, nationals as well as foreign nationals, are unrecorded: while, for nationals, it can, at most, be a disadvantageous situation, for nonnationals, it is a breach of the law, as every country in the region demands that foreign workers have a work permit. Recently, irregular labour migration has been rising in conjunction with, on the one hand, employers' interests in recruiting migrants whose illegal situation is a reason for accepting lower wages than natives, and, on the other hand, governments' protectionist policies that reserve an increasing number of professions for nationals, thereby turning regular migrants employed in these professions into irregular ones.

In the Maghreb, Libya was the main destination for migrant workers, regular as well as irregular, until the uprisings of 2011 that emptied the country of a large part of its foreign national residents. The country had been transformed, beginning in the 1970s, into a major labour market for migrant workers by an exceptional combination of capital surpluses (the oil economy) and labour shortages (a scarce indigenous population). It was

25) Philippe Fargues, "Work, Refuge, Transit: An Emerging Pattern of Irregular Immigration South and East of the Mediterranean," International Migration Review 43, no. 3 (Fall 2009): $544-577$. 
the exodus provoked by the uprising in 2011 that revealed the true magnitude of migrant stocks in the country: 706,073 foreign nationals were recorded as crossing the land borders from Libya to a neighbouring state between February and September 2011, comprising 140,642 Egyptians returning to Egypt; 96,913 Tunisians returning to Tunisia; 292,772 thirdcountry nationals entering Tunisia or Egypt; 148,281 migrants entering other African countries bordering Libya; and 27,465 migrants and refugees of all nationalities fleeing from Libya to Italy or Malta. ${ }^{26}$ Taking into account those still in Libya and those who left the country without being counted, these numbers indicate that the true foreign population living in Libya was, by far, larger than the 450,000 officially recorded as legal immigrants.

For Libya, under Col. Kaddafi, immigration was a matter of labour policy as well as external policy. The Jamahiriya, which had successively welcomed Arabs in the name of Pan-Arabism, then Africans in the name of Pan-Africanism, suddenly imposed visas on both in 2007 - a measure that turned most Arabs and Africans in Libya into irregular migrants - as a bargaining chip in obtaining international rehabilitation in exchange for controlling the external border of Europe, at a time when Libya had become a staging post for irregular migrants on their way across the Mediterranean. ${ }^{27}$

The only other country in the Maghreb with a sizeable stock of migrant workers is Algeria. Despite extremely high rates of unemployment among its young, Algeria has become an attractive labour market for tens of thousands of Sub-Saharan migrants who bring a critical workforce to the economy of the deserts in Southern Algeria, but also for some 35,000 Chinese workers in the construction sector and other semi-skilled activities. So far, Morocco, Tunisia, and Mauritania, which are important transit points on the routes of global migration to Europe, do not retain many international migrants in their own labour markets.

In two countries of the Mashrek, Lebanon and Jordan, migrant workers comprise between one quarter and one third of the total workforce and they represent a majority in specific sectors. In Lebanon, the Syrian workforce has continuously brought, since the 1960 s, a critical contribution to

26) IOM, External Situation Report, responses to the Libyan crisis, March 222011 (2011), April 72011 (2011e); and May 262011 (2011).

27) European Commission, Technical Mission to Libya on Illegal Immigration, report doc. no. 7753/05, November 27 - December 6, 2004.; Sylvie Bredeloup and Olivier Pliez, "The Libyan Migration Corridor," EU-US Immigration Systems, European University Institute 3 (2011). 
many low-skilled activities in agriculture, construction, petty trade, and services. ${ }^{28}$ With hundreds of thousands of Lebanese nationals fleeing the country, the 1975-1989 Civil War was an occasion for more Syrian workers to take up the empty positions on the Lebanese labour market and their number was estimated at 0.5 million in 2005. The suspected involvement of the Syrian government in the 2005 assassination of former Prime Minister Rafic Hariri, the popular anti-Syrian mobilisation it triggered, and the subsequent withdrawal of the Syrian army from Lebanon scapegoated Syrian migrant workers and provoked their return en masse to their home country. A year later, however, they were believed to be back in Lebanon in equal numbers.

In Jordan, it was migration to the Gulf from the 196os onwards that created shortages in the local labour market and that called for replacement migration. Egyptian migrants came from the Nile Valley to farm the Jordan River valley exactly the same way as they did in the Euphrates and Tigris valleys to replace Iraqi conscripts. Other migrants, mostly from South Asia, were attracted by employment in the Qualifying Industrial Zones (QIZ) created in the 199os to manufacture goods in Jordan that can access the United States market under the free-trade agreements between the United States and Israel.

The Mashrek lies at the crossroads of major refugee movements of the last two decades. They originate in Iraq, Sudan, the Horn of Africa, and other parts of Africa and are mainly hosted by Jordan, Syria, Lebanon, and Egypt. Since 2011, with popular uprisings turning violent in Libya and Syria, refugees have also come from within the region itself. It must be remembered that the most massive and, indeed, the oldest refugee population in the world are the Palestinians who originated and, for the most part, still live in the region. Most Palestinian refugees are not themselves migrants but second or third generation descendants of those who fled Palestine in 1948 or those who were displaced in 1967 , and, therefore, they are not dealt with in this paper on current migration.

Other than the Palestinians, refugees hosted by Mashrek countries are equal or greater in number than migrant workers there. But, it is not known

28) John Chalcraft John, The invisible cage: Syrian migrant workers in Lebanon (Stanford: Stanford University Press, 2009); Zaki Mehchy and Amer Mhadi Doko, "General overview of migration into, through and from Syria," CARIM Analytic and Synthetic Notes 2011/41 (Florence: EUI, 2009). http://cadmus.eui.eu/handle/1814/17794. 
exactly how many there are and for how long they will stay. Waves of refugees fleeing war-torn countries - in the first instance, Iraq, but also Sudan, Somalia, and Eritrea - have found shelter in Jordan, Syria, Lebanon, and Egypt. While they were immediately accepted as guests and often generously provided with first aid, they were seldom granted refugee status. States acknowledge the fact that they are countries of first asylum, but they also claim that they lack the economic resources, or the political will, to become countries of permanent resettlement. In the case of Jordan, Syria, and Lebanon, which were the main receivers of the Palestinian exodus of 1948-49 and which never signed the Refugee Convention of 1951, it is also because the state does not recognise refugees other than the Palestinians. For these reasons, recent refugees in the Mashrek are de facto, rather than dejure, refugees. Because refugees are not officially recognised and recorded as refugees, they are not properly counted by states and their numbers are subject to manipulation.

Iraqi refugees are a case in point. According to UNHCR, between 2 and 2.5 million Iraqi refugees were sheltered in neighbouring countries in 20072008. This number fits in well with those declared by the receiving states: $75^{0}, 000$ in Jordan; 1,200,000 in Syria; 100,000 in Lebanon; and 170,000 in Egypt. Surveys, however, provide different figures. In 2007, the Norwegian research Institute FAFO and the Department of Statistics of Jordan found a much lower 161,000, an estimate that was revised ex-post to 450,000-500,000 to take into account the fact that unknown numbers of Iraqis would have concealed their true nationality for fear of deportation. ${ }^{29}$ In Egypt, a statistical survey carried out in 2008 by the Information and Decision Support Center of the Prime Ministry and the American University in Cairo found 17,000 Iraqi refugees, instead of the 150,000 claimed by the government and UNHCR. ${ }^{30}$ In Lebanon, in 2007, the Danish Refugee Council found 26,368 Iraqi refugees, a number eventually re-estimated at 50,000-100,000 "to arrive at a range of numbers that appear logical to key stakeholders". ${ }^{31}$ In Syria,

29) FAFO 2007, Iraqis in Jordan. Their Number and Characteristics, http://fafo.no/ais/ middeast/jordan/Iraqis_in_Jordan.htm.

30) Philippe Fargues, et al., Iraqis in Egypt. A Statistical Survey in 2008, The American University in Cairo and Information and Decision Support Centre, 2008, http://www .aucegypt.edu/ResearchatAUC/rc/cmrs/Documents/Iraqis\%2oin\%2oEgypt\%20 Provisional\%20Copy.pdf, 95.

31) Aziza Khalidi, \& al. 2007, "Danish Refugee Council 2007," in Iraqi Population Survey in Lebanon. A Report, (Beirut, November 2007), available at: http://dalil-madani.org/resources/ Iraqi\%2oPopulation\%20Survey\%20-\%20English.pdf. 
where no survey was carried out, it seems difficult to accept the official estimate of 1.2 million knowing that 80 to 90 per cent of the Iraqi refugees were living in the Damascus area, ${ }^{32}$ which would mean that one out of every three or four persons in the capital city of Syria was, and still is, an Iraqi refugee.

Why states - and UNHCR - seem to have inflated numbers of Iraqi refugees is unclear: Was it to raise awareness of the refugees' plight and, so, trigger a humanitarian mobilisation? Was it to arouse international solidarity with the host states and create mechanisms of burden sharing? Was it to distract local opinions from governance failures and, so, put the responsibility for internal problems, such as growing inflation or rising insecurity, on foreign nationals?

Not giving a status to refugees may produce the opposite result - that is, an underestimate of their numbers. This was the case in Libya under Col. Kaddafi. Libya is not party to the 1951 Refugee Convention and its government was simply postulated that every foreign national in the country was an economic migrant, whether legal or unauthorized, and that refugees did not exist in Libya. However, as many nationals from Sudan, Somalia, Eritrea, and other African countries who entered Libya and found employment there had legitimate fear of returning home, migrant workers often hid genuine de facto refugees. Being considered economic migrants and not refugees, they could be deported, as they did not have legal documents to stay. And, actually, Libya under Col. Kaddafi had a regular practice of largescale deportation of African migrants without any possibility of them lodging an asylum claim.

\section{Integrating immigration: open societies vs. closed citizenries}

There are differences between the Mashrek and the Maghreb in terms of the way that immigrants are received by societies and states. These differences reflect a fundamental division in the Arab region with regard to immigration. East of Egypt, the international, but largely intra-regional,

32) Patricia Weiss Fagen Iraqi Refugees: Seeking Stability in Syria and Jordan (Washington D.C.: Institute for the Study of International Migration, Georgetown University, 2007), 19, available at http://www12.georgetown.edu/sfs/qatar/cirs/PatriciaFagenCIRSOccasional Paper2009.pdf. 
mobility of persons is a legacy of the Ottoman Empire ${ }^{33}$ and a genuine form - actually, the only form - of Arab regional integration. West of Egypt, intra-regional mobility is limited to Libya attracting temporary male labour migrants and, despite the fact that the Maghreb has always been in economic continuity with sub-Saharan Africa and open to its merchants and migrants, the reception of international migrants has recently changed under the influence of an external factor, namely the asymmetric relationship between Maghreb and European states on migration issues.

Over the last hundred years, in the Mashrek, societies have demonstrated an unbeaten openness to sudden waves of refugees and migrants and they have absorbed, in record time, large numbers of newcomers. The simple fact that hundreds of thousands of Iraqis flooding into Jordan or Syria in 2005 and 2006 could be accommodated in local neighbourhoods and not in camps tells much about how open these societies are. At the time of writing, the same story seems to be repeating itself with tens of thousands of Syrian refugees finding shelter in Lebanese and Jordanian villages and towns.

Governments did not close the doors on refugees and migrants either. Indeed, they often facilitated their entry and temporary stay. However, they seldom adopted legislation to integrate them into the citizenry and, in most cases, they limited, or denied, their access to social rights (Table 6). Moreover, apart from Jordan, naturalisation has nowhere been an option for migrants and refugees. Nor has it been an option for their sons and daughters: three generations after the Nakba, the exodus of 1948, Palestinians are still stateless people in the Arab countries where their ancestors found shelter and where they have remained since then. As nonnationals, they are subjected to restrictions applying to aliens regarding access to public school or health as well as to the labour market. In Lebanon, Palestinians were always excluded from a list of seventy professions. A law that partly lifted this restriction was prepared in 2005 and ratified by the

33) The Ottoman state had established early rules for accommodating immigrants and created, in 1860, a commission (Muhacirin Komisyonu) to regulate immigration and settlement. While the Commission was in charge of applying the old Islamic ethics of accommodating migrants, it had also a mission to "use migration as a source of manpower and to rebuild the society according to new, modern ideas and aspirations and new models of social organization”. Karpat, "Muslim Migration", see note 5. 
Table 6 Selected legislation governing immigration in Arab Mediterranean countries

\begin{tabular}{ll}
\hline Country & Legislations \\
\hline $\begin{array}{l}\text { Mashrek } \\
\text { Egypt }\end{array}$ & $\begin{array}{l}\text { Law } 88 \text { of } 2005 \text { on the entry, stay, and exit of foreign nationals. } \\
\text { Arab citizens are now submitted to the same entry conditions } \\
\text { as other foreign nationals. Sanctions for irregular entry and stay } \\
\text { are strengthened, but remain much lower than in Maghreb } \\
\text { countries. }\end{array}$
\end{tabular}

Jordan Law $\mathrm{n}^{\circ} 24$ of 1973 on Residence and Foreign Nationals' Affairs, modified by Amendment $n^{\circ} 90$ of 1998 . Immigration is considered temporary and a response to needs in the national economy. Arab nationals are privileged regarding entry, stay, and access to citizenship. Irregular entry and stay are penalized with prison and fine. Employment of irregular workers is punished. The irregular worker is deported. Deportation decisions can be judicially challenged, though these challenges have no effec. Law $\mathrm{n}^{\circ} 48$ of 2008: domestic and agriculture workers are covered by Labour Law. A Letter of Understanding in 2003 for the creation of a Border Center and for the temporary protection of Iraqi nationals.

Lebanon Bilateral agreement of 1994 with Syria on employment of Syrian nationals. Circulation between Lebanon and Syria facilitated for nationals from both countries and for Palestinian refugees.

Palestine Israeli Military Order $n^{\circ} 165^{\circ}$ of 2009 : any person who irregularly enters into or stays without permit in the West Bank will be considered an infiltrator and may be punished with a sevenyear prison sentence.

Syria

Decision $\mathrm{n}^{\circ} 1350$ of 15 August 1984: entry without visa for nationals from all Arab states, from the Gulf, from the Emirates, and from the Sultanates. Entry visa requirement re-established for Iraqis in 2007 (decision $n^{\circ} 30$ of 2007). Access to Employment: Laws $\mathrm{n}^{\circ} 5^{\circ}$ of 2004 and $\mathrm{n}^{\circ} 17$ of 2010 : ministerial authorisation is needed, based on the list of professions open to aliens and reciprocity with the origin country. Work permit required. Arab nationals have facilitated access to most of professions.

Maghreb Algeria

Law ${ }^{\circ} 08-11$ of 2008 governing the entry, stay, and circulation of foreign nationals. Law $\mathrm{n}^{\circ} 09$-01 of 2009 , modifying the Penal code to add the offence of irregular exit from its territory for its citizens and foreign residents, the offence of marriage of convenience, and the crime of migrant smuggling and trafficking in persons. 
Table 6 (Cont.)

\begin{tabular}{|c|c|}
\hline Country & Legislations \\
\hline Libya & $\begin{array}{l}\text { Visa requirements for all, except nationals from the Maghreb. Exit } \\
\text { visas needed for foreign residents. Law } n^{\circ} \mathrm{O} 2 \text { of } 2004 \text {, Law } n^{\circ} 19 \\
\text { of } 2010 \text { to combat irregular migration. Prison penalty and fine } \\
\text { for the facilitation of irregular entry or exit. Decree } n^{\circ} 6 \text { of } 2007 \\
\text { listing professions open to aliens. }\end{array}$ \\
\hline Mauritania & $\begin{array}{l}\text { No visa requirement for nationals of states linked to Mauritania } \\
\text { by circulation or/and establishment conventions. Decree of } \\
\text { April } 16,2008 \text { related to the employment conditions of foreign } \\
\text { manpower: equal access to employment, low implementation } \\
\text { of penalties against irregular employment. }\end{array}$ \\
\hline Morocco & $\begin{array}{l}\text { Law } \mathrm{n}^{\circ} \mathrm{O} 2-\mathrm{O} 3 \text { of November } 11,2003 \text { on the entry and stay of for- } \\
\text { eign nationals into Morocco, emigration, and irregular immi- } \\
\text { gration: strengthens repression against people who facilitate or } \\
\text { organize irregular entry or exit; penalizes irregular immigrants } \\
\text { or emigrants, should they be foreign or national citizens; intro- } \\
\text { duces legal rights and protective instruments. } \\
\text { Article } 30 \text { of the Constitution of } 2011 \text { grants foreign residents the } \\
\text { same fundamental rights and freedoms as Moroccan citizens, } \\
\text { including the right to participate (i.e. to elect and be elected?) } \\
\text { in local elections. }\end{array}$ \\
\hline Tunisia & $\begin{array}{l}2004 \text { migration law reinforcing penal sentences against assistance } \\
\text { to irregular migration: up to } 3 \text { years in prison and 8ooo dinars } \\
\text { fine for people who contribute, even without profit, to irregular } \\
\text { migration; up to } 4 \text { years in prison for hosting a 'clandestine'. } \\
\text { Non-denouncement is also punished. }\end{array}$ \\
\hline
\end{tabular}

Source: CARIM Migration Profiles, by country, http://www.carim.org/index.php ?callContent $=502$

parliament in 2010, but, in 2012, the ministerial decree that would have implemented this law remained unsigned. ${ }^{34}$

The Jordanian exception must be mentioned here. In Jordan, all Palestinians who came from those areas that became Israel in 1948 or were annexed by Israel in the course of the 1948-49 War were granted Jordanian nationality (Law No.56/1949). In addition, when the West Bank was annexed by Transjordan in 1950 to form the Hashemite Kingdom of Jordan, its

\footnotetext{
34) Sari Hanafi, "Stop humiliating Palestinian refugees," The Daily Star, Beirut, March 16,
} 2012. 
Palestinian population, natives as well as refugees, was granted Jordanian nationality (Constitution of 1952, Article 5). However, this measure would later prove to be reversible when, in 1988, the King of Jordan unilaterally decided to sever legal and administrative links with the West Bank. All Jordanian citizens of Palestinian origin residing in the West Bank lost their Jordanian nationality without having recourse to Palestinian nationality because of the non-existence, from a legal point of view, of a Palestinian state that could grant Palestinian citizenship, and in violation of the Jordanian Constitution. ${ }^{35}$

The same situation of open societies contrasting with closed citizenries as observed in the Mashrek applies to the Maghreb. Integrating foreign residents through ultimately providing them with legal access to nationality is exceptional, if not impossible. While Algeria, Mauritania, Morocco and Tunisia are still small receivers of global migrants, decades of emigration to Europe has brought back to them some return migration, including couples of mixed descent whose children are born in the Maghreb. When the father is a national, the children are themselves born citizens in compliance with the prevailing jus sanguinis by paternal descent. This principle, however, does not apply if it is the mother who is a national. To respond to a relatively frequent situation with sometimes dramatic consequences (when divorce or widowhood leaves a national mother with children who, as foreign nationals, have no access to rights reserved to citizens), Mauritania and Tunisia, in the 1960s, ultimately followed by Algeria and Morocco (as well as Egypt) in the 2000s, have extended jus sanguinis to children born in the country from a national mother and a foreign-national father. This change must be credited to women gaining increasing rights in the Maghreb $^{36}$ and probably not interpreted as a step towards integration of immigrants.

Actually, children born on the territory to parents who are both foreign nationals have no access to citizenship, except in Morocco in the very limited case when the two parents themselves where born in Morocco after the independence. While legal provisions for naturalising foreign nationals exist, they are limited to those of Arab descent and seem to be very rarely applied. Naturalisation is the ultimate form of integration. Intermediate

35) Assem Khalil, "Palestinian Refugees in Arab States: A Rights-Based Approach," CARIM Research Report 2009/o8, available at: http://cadmus.eui.eu/handle/1814/10792.

36) Delphine Perrin, "Immigration and Citizenship Law in the Maghreb: Turning Aliens into Citizens," EUDO Citizenship Observatory, EUI Working Papers 40 (Florence: EUI, 2011). 
forms may consist in granting citizen-like rights to immigrants without granting them citizenship. Noticeably, Morocco seems to be poised to pave the way in this direction, as its 2011 constitution recognises to foreign national residents the same fundamental rights as to Moroccan citizens. ${ }^{37}$

What makes the Maghreb specific is that part of its most recent immigration is explained by tightened European border control, leaving many migrants initially bound to the EU stranded at its external border. Therefore, both the immigration the Maghreb receives and the emigration it sends link Maghreb states to European states and, as a consequence, their policies on immigration and their policies on emigration are linked too. In their concern to contain irregular immigration originating in or transiting through the Maghreb, Mediterranean European states sought the cooperation of Maghreb states in controlling movements towards their borders. For Maghreb states, this meant taking measures such as criminalising irregular migrants and returning them to the border, which may prejudice their relations with Sub-Saharan African nations. They accepted to control irregular migration only because it was part of a larger approach linking together the various aspects of migration and responding not only to Europe's agenda (security), but also to their own agenda (development through labour emigration). In particular, controlling exits from their territory has become a bargaining chip for Maghreb states to negotiate better visa policies.

Talks between Maghreb and European states to define the 'joint management' of international migration started in the 1980s, at the initiative of France and Italy, and resulted, in the early 200os, in the launching of a consultative process under the auspices of the International Organisation for Migration: the ' $5+5$ Dialogue on Migration in the Western Mediterranean', providing for the joint management of international borders, labour migration, development, and the protection of the rights of migrants. A few years later, the process was extended to Sub-Saharan African countries (Euro-African ministerial conferences of Rabat in 2006, Paris in 2008, and Dakar in 2011) and three lines of cooperation were defined: organising legal migration, including mobility facilitation and the guarantee of migrants' rights; fighting against irregular migration, including border management,

\footnotetext{
37) Article 30 of the 2011 Constitution of Morocco states: “ [...] Les étrangers jouissent des libertés fondamentales reconnues aux citoyennes et citoyens marocains, conformément à la loi. Ceux d'entre eux qui résident au Maroc peuvent participer aux élections locales en vertu de la loi, de l'application de conventions internationales ou de pratiques de réciprocité [...] Khalil, "Palestinian Refugees", see note 35.
} 
readmission procedures, and the protection of vulnerable groups; and fostering development through migration.

It must be noted that the need to maintain good relations with Europe and African States on the contentious issue of migration does not fully account for Maghreb states' policymaking on immigration. Protecting their national security was a strong motivating factor behind the new legislation that the three central Maghreb states adopted, starting with Morocco in 2003, then Tunisia in 2004, and, finally, Algeria in 2008 (Table 6). These laws provide for severe penalties not only for traffickers, but also for migrants themselves. But, they do not contain regulations to protect migrants against maltreatment by employers or the authorities. They also criminalise unauthorized exit from the country in apparent breach of International human rights law, which recognises the right to leave any country. In Morocco, but not in Tunisia and in Algeria, the new law was strongly criticised by NGOs and human rights activists.

\section{Conclusion}

With the advent of the nationstate in the course of the twentieth century, long-distance migration, both outwards and inwards, has become international and a matter for state policymaking. In a first stage of the nationbuilding process, Arab states took little interest in their expatriate communities. Instead, they mistrusted a population suspected to be infiltrated by political exiles and opponents to the newly established regimes. It is only much later, in the wake of IMF-inspired neoliberal economic policies opening borders to goods and monies, that Arab states started to look differently at their diasporas and to regard them as an interesting resource that could be mobilised for boosting national development. They developed tools in order to incorporate their expatriate communities in the economy, then to maintain among their members a sense of belonging to the homeland, and, finally, in some cases, to suscitate their political participation.

Immigrants were dealt with differently. Often incorporated with no distinction between them and natives when the nation was in the making like Armenians in Lebanon, who became one of the founding communities of the Lebanese nation - they stopped being eligible for full membership once the nation became established. Since then, migrants and refugees have continued to enter and settle and they often play a significant 
economic role by filling positions that no longer attract nationals, but very few of them are admitted in the citizenry. On the contrary, because they are employed in informal activities that open no way to regularisation and, therefore, no entitlements, apart from basic human rights, many remain in the margins of society and form a vulnerable outcast population.

A considerable shift has, thus, taken place in a few decades. Most Arab states are creations of the twentieth century and their nationality was defined so as to formally solidify a bond between people sharing a common allegiance. Territory and ascent, i.e. jus soli and jus sanguinis, were combined to define nationals as people born on the territory of the nation at a date regarded as founding the nation (e.g. accession at independence) and their descendants by patrilinear descent. But jus soli was immediately relegated and, today, being born on the territory of the nation from foreign national parents opens nowhere a right to nationality in the Arab world. While international migration is universally linked with nationhood and can be used to expand the nation in two complementary ways from within by integrating immigrants and from without by linking with diasporas - all Arab states have renounced the former and kept only the latter. 